\title{
Pedagogicko-psychologická diagnostika jako zadní dvorek psychologické diagnostiky?
}

\author{
JAN MARE ̌́ \\ Katedra psychologie a Institut výzkumu dětí, mládeže a rodiny FSS MU
}

\begin{abstract}
Abstrakt: Diskusní př́spěvek připomíná pedagogicko-psychologickou diagnostiku jako jednu z významných oblastí psychologické diagnostiky. Na proklamativní úrovni je individualizace výuky jedním z ústředních témat změn probíhajících ve vzdělávacím systému od 90. let a logicky přináší požadavek na lepší znalost individuálních specifik jednotlivých žáků. Diagnostická praxe ale tento rozvoj kopíruje jen částečně. Historicky rozvinuté oblasti pedagogicko-psychologické diagnostiky si udržují svou úroveň, řada nových témat a oblastí ale zůstává opomíjena a je řešena neuspokojivým zpưsobem s logickými důsledky pro celý vzdělávací systém, tvorbu a použití diagnostických nástrojů i pro konkrétní žáky či studenty. Pedagogicko-psychologická diagnostika tak přestala být diagnostickou výkladní skřiní a stal se z ní spíše zadní dvorek diagnostiky, jakkoli s ní má zkušenost prakticky celá populace. řadu diagnostických aktivit voblasti výchovy a vzdělávání navíc můžeme chápat jako př́klad tzv. high-stakes diagnostiky. V př́spěvku se pokouším pojmenovat některé problematické části systému profesní př́pravy uživatelů diagnostických nástroju a jejich výsledků i vzdělávací politiky a její implementace v podobě predpisů upravujících diagnostiku v oblasti výchovy a vzdělávání.
\end{abstract}

Klíčová slova: Pedagogicko-psychologická diagnostika, profesní príprava učitelů, profesní príprava psychologů, výuková praxe, klasická teorie testů

\section{Úvodem}

Z historických důvodů i zhlediska intuitivně uchopované prestiže jednotlivých psychologických specializací je odbornou veřejností jako problém vnímána spíše klinická diagnostika. Pedagogicko-psychologická diagnostika není v rámci oboru vnímána jako zásadní problém, částečně i proto, že část diagnostických aktivit se v této oblasti rozpustila do činnosti dalších profesí či semiprofesí (srv. Evers et al. 2012). Osobně se ale domnívám, že minimálně stejnou pozornost si zasluhuje oblast pedagogicko-psychologické diagnostiky, se kterou má v populaci prakticky každý, má podobně dalekosáhlé konsekvence a jako problém je komplexnějším způsobem zatím 
řešena jen v př́ípadě specifických problémů (např. šikany) či specifických skupin žáků (příslušníků minorit, nadaných či integrovaných). Příklady ilustrujícím všeobecně neuspokojivý stav této oblasti nemusíme hledat dlouho. Z hlediska výsledků kritických typů diagnostických rozhodnutí o žácích a studentech ne zcela uspokojivým způsobem prakticky zvládnutým patří státní maturity či plošné srovnávací testy v páté a deváté tř́ídě základní školy. Problematických míst při jejich vzniku bylo několik. Připomeňme amatérskou tvorbu jak vlastních bank testových úloh (ve smyslu „pošlete otázky a my něco vybereme“), stejně ale byla při řešení zákonitě vzniklých problémů překvapivá i inovativní myšlenka testové položky jako indikátoru konkrétní charakteristiky. V uvedených případech se jedná o otázku dosažení vzdělávacích cílů a kupodivu i o neschopnost je definovat dříve, než se pokusíme o vlastní testování. Argumenty ve prospěch zavádění těchto výkonových testů byly spíše kargokultické povahy (srv. Novotný, 2000) - dělají to všichni kolem, takže je to určitě dobrý nápad. Z pohledu oboru je možná dobré, že řada maturantů se nedobrovolně stala experty na problematiku didaktických testů a validitu jejich výsledků, celkově ale vidíme symptomy úpadku znalostí považovaných ještě v nedávné době za nedílnou součást pregraduální př́pravy učitelů či psychologů. Snaha o zvrácení tohoto trendu bude běh na dlouhou trat', nebot' vyžaduje řešení celé řady systémových problémů, at' už se jedná o matematickou gramotnost, kompetence uživatele testů i celkovou odbornou prestiž oblasti.

\section{Učitel jako klíčový prvek systému}

V laickém pohledu je někdy oblast pedagogicko-psychologické diagnostiky chápána jen jako aktivita institucí, které poskytují specializovanou diagnostickou a poradenskou činnost jako službu školám a školským zařízením. Tato představa je však mylná. Pedagogicko-psychologická diagnostika je primárně aktivitou učitele (srv. Kožuchová a kol, 2011). Bez jeho zkušeností, znalostí a odborného odhadu je komplexní posouzení silných a problematických stránek konkrétního žáka obtížné, ne-li nemožné. Jednorázové vyšetření totiž nemůže nahradit průběžné sledování aktivit studujícího a znalost kontextu situací, ve kterých se vyskytují případné studijní či jiné obtíže konkrétního žáka nebo studenta. 
$\mathrm{V}$ tradičních př́stupech $\mathrm{k}$ tomuto tématu je hlavní pozornost věnována jednotlivým diagnostickým nástrojům. S ohledem na to, že v současnosti je nabídka kvalitních diagnostických nástrojů poměrně omezená a je dostatečně popsána v jiných zdrojích (např. Svoboda, Krejčířová, Vágnerová, 2011; Hrabal a Hrabal, 2002), považuji za užitečnější věnovat pozornost jednak širšímu kontextu pedagogicko-psychologické diagnostiky jako jednomu z nástrojů vzdělávací politiky a dále také jako způsobu, jak můžeme hledat odpovědi na každodenní otázky, které přináší vzdělávací praxe a na které - bohužel - v procesu edukace zbývá málo prostoru a je jim věnována obecně malá pozornost.

Jedním z velkých paradoxů současného vzdělávání je totiž právě problematická situace v oblasti nabídky jednoduchých screeningových nástrojů pro běžné, každodenní použití ve škole - jakkoli je verbálně proklamován individuální př́stup a ohled na specifické vzdělávací potřeby jednotlivých žáků. Smutným faktem zůstává, že učitel v běžné české školní trrídě má - videálním případě - informace o vzdělávacích potřebách žáků se speciálními výchovně-vzdělávacími potřebami (poruchy učení atp.), žáků integrovaných (jsou např. součástí individuálního vzdělávacího plánu) či žáků nadaných. Psychologové, rodiče a širší odborná veřejnost však museli u každé této skupiny důrazně probojovávat specifický př́ístup a jeho oporu v legislativě (v podobě vyhlášek) s doporučeními pro diagnostiku. Průměrný žák, který nevykazuje nějaké výrazné zvláštnosti, jako kdyby z centra pozornosti vypadl a jeho proces učení, profesní orientace či možnosti optimalizace školního výkonu nejsou problematikou, která by se těšila všeobecné vážnosti či důrazu. Minimálně na úrovni nabídky diagnostických nástrojů pro potřeby práce konkrétního učitele. Může to být ovlivněno i tím, že někteří učitelé bohužel nechápou pedagogicko-psychologickou diagnostiku jako součást své profesní role a svou roli v procesu pedagogicko-psychologické diagnostiky chápou jen jako zadavatelskou či servisní. Či dokonce zařazení žáka do některé ze skupin, které mají legislativně ukotven požadavek specifického přístupu učitele, používají jako nadávku („Ty jeden dyslektiku!“; Štech a kol., 1995).

Běžné metody a nástroje v práci učitelů navíc nejsou v pregraduální přípravě (patrně $\mathrm{v}$ důsledku masifikace studia a jejich časové náročnosti ve výuce) př́liš trénovány, at' už se jedná o pozorování (nepřipravené, či připravené v podobě hospitace), dovednost 
vedení rozhovoru, analýzu dílčích produktů činnosti či portfolia (jako příklady komplexní diagnostiky).

Specifickou skupinu pak tvoří vědomostní testy a nejrůznější dotazníky či škály, které jsou mnohdy připravovány spiše intuitivně, nebot' klasická teorie testů se stala spíše symbolickou součástí pregraduální přípravy a její praktické uplatnění není vyžadováno. To má své systémové důsledky, kdy jsou učiteli používány diagnostické nástroje, které vznikly pro jiný účel, s mnohdy problematickými psychometrickými parametry (nebo zcela chybějícími), sporným způsobem přeloženy či s neřešenou otázkou autorských práv. Tento stav je považován za natolik samozřejmý, že i větší nakladatelství vydávají publikace, které ilustrují všechny vyjmenované problémy najednou (viz např. recenze Mareš, 2011). V širším kontextu tuto problematiku můžeme chápat jako velký etický problém a jednu z výzev při vytváření českého standardu pro používání psychologických testů (srv. Ježek, 2010).

Samostatným okruhem problémů je pak použití nástrojů, které jsou zhlediska konstrukce snadno pochopitelné, ale mohou mít v rukou laika řadu vedlejších dopadů a svým zaměřením mohou přispět ke vzniku problémů, kterým měly předcházet (např. sociometrie a efekt „veřejně známého neoblíbeného žáka“).

V posledních letech také můžeme sledovat s př́livem prostředků z projektů EU do školství další fenomén a to jsou odborně sporné komerční aktivity (např. Barvy školy či Socioklima), kdy jedním z hlavních argumentů pro jejich použití - krom nedostatečné kompetence posoudit jejich problematičnost nebo tlaku ze strany nadřízených institucí - je jejich dostupnost a snadnost vyhodnocení „přes počítač“ bez chápání limitů (např. Širůček, 2010) tohoto typu diagnostiky. I když existují alternativy, které prošly standardním procesem odborné oponentury a standardizace (např. Chvál, Michek a kol., 2012), z pohledu uživatelů nástrojů mezi nimi není zřejmý rozdíl, což je výhledově jedním z hlavních kritických momentů pro budoucí rozvoj diagnostiky v této oblasti. 


\section{Instituce pedagogicko-psychologické diagnostiky $v$ ČR}

V této oblasti lze patrně za posledních 20 . let vidět největší posun, který by se dal charakterizovat změnou od segregace k integraci ve smyslu tlaku na umist’ování dětí se specifickými výchovně vzdělávacími potřebami v hlavním vzdělávacím proudu. To je doprovázeno i s postupnou změnou vtom, co se vrámci pedagogické psychologie označuje jako pedagogické myšlení učitele, učitelovo pojetí výuky a zejména zásadní změna $\mathrm{v}$ „modelu žáka“. Tak, jak se změnila společnost z hlediska různosti hodnotových orientací, kulturního zázemí, výchovných stylů atd., dochází stále ke změnám v myšlení učitelů při subjektivním vymezování kategorií, jako je ideální žák, vzdělavatelný žák, zlobivý žák atd.

Další výraznou změnu přinesly posuny v organizačním zajištění psychologických služeb pro školy. Tuto změnu bychom mohli stručně charakterizovat jako posun od psychologa pro školy k psychologovi ve škole (rozvoj školních poradenských pracovišt’ a profese školního psychologa ${ }^{1}$ ). Trendem, který je rovněž vhodné připomenout, je etablování semiprofesí a přesun některých diagnostických činností mimo profesní rámec psychologie.

Jak tedy funguje systém pedagogicko-psychologické diagnostiky u nás? V principu můžeme odlišit dvě základní úrovně, kdy první je rutinní (pedagogická a psychologická) diagnostika učitele v běžné výuce a navazuje na ni vlastní poradenský systém. Obecným teoretickým rámcem pro fungování systému je chápání vzdělávání jako nástroje změny. V této souvislosti je široce diskutován a obecně přijímán koncept rovných příležitostí (equal educational opportunity), který vychází ze snahy vyrovnávat podmínky pro vzdělávání (různé sociální složení třídy, různá kognitivní úroveň vs. stejní učitelé) a poskytovat stejnou péči na úrovni konkrétní školy. Koncept rovných př́ležitostí je obsažen jak v obecných politických vizích vzdělávací politiky v EU a v ČR, tak i na úrovni jejich praktické implementace v podobě reformních snah např́íc Evropou.

Jaké jsou tedy požadavky v této oblasti na praxi školy a činnost konkrétních učitelů? Škola se současně snaží dosahovat tzv. „funkčního minima“ žáků a vyrovnávat jejich

\footnotetext{
${ }^{1}$ Více informací o historii i současnosti profese školní psycholog na stránkách Asociace školní psychologie
} dostupných z http://schoolpsychology.cz. 
dosahované výsledky (jedná se o jednu z charakteristik sledovanou i na mezinárodní úrovni např. ve výzkumech PISA).

Klíčovou figurou v tomto procesu integrace je učitel (srv. Kožuchová a kol. 2011). Reálně je ale další nutnou podmínkou fungování poradenského systému v ČR i aktivní přístup rodičů (předškolní věk dětí a školní věk), učitelů (školní věk, adolescence a mladší dospělost) i studujících samotných (školní věk, adolescence a mladší dospělost), a to is ohledem na známé problémy zmíněné vúvodu tohoto studijního modulu. Screeningovou diagnostickou činnost (ekvivalent preventivních lékařských prohlídek) bohužel nemůžeme považovat za bez potíží fungující součást systému. Obecně můžeme konstatovat, že poradenský systém je spíše reaktivní (řeší problémy) než preventivně orientovaný.

Je nutné si uvědomit, že více informací o žákovi či studentovi přináší i větší zodpovědnost, vkontextu pedagogických a psychologických teorií se nabízí např. koncept subjektivní zodpovědnosti za úspěch žáka (který můžete znát i ze sociální psychologie jako atribuování úspěchu či skupinovou atribuci - v př́ípadě více učitelů jednoho žáka; Mareš Jiř́i in Čáp, Mareš Jiří, 2001).

Poradenský systém v rámci vzdělávacího systému zahrnující vlastní expertní pracoviště má pak poměrně jednoduchou strukturu, která vychází ze dvou základních pilírũ.

První pilír tvoří činnost školních poradenských pracovníků, na školách je někdy označována termínem „školní poradenské pracoviště“. Nejedná se však o samostatnou organizační formu nebo o jednotku v rámci školy, která má nebo by měla mít právní subjektivitu. Školní poradenské pracoviště je $\mathbf{v}$ základní formě tvořeno činností školního metodika prevence a výchovného poradce. $\mathbf{V}$ rozšířené formě školního poradenského pracoviště je $\mathrm{k}$ metodikovi a poradci doplněn školní speciální pedagog nebo školní psycholog. $V$ případě některých škol ve školním poradenském pracovišti najdeme všechny vyjmenované školní poradenské specialisty, jejichž činnost je financována bud’ z vlastních zdrojů, nebo z různých grantů a dotací EU.

Druhým piliřrem poradenského systému ve školství jsou tzv. školská poradenská zařízení. Tvoří je pedagogicko-psychologické poradny a speciálně pedagogická centra. Tato zařízení zajišt'ují specializovanou diagnostiku a jsou oprávněna vydávat rozhodnutí směřující ke specifickému přístupu ke konkrétnímu žákovi na úrovni konkrétní školy. 
Souhrnně ale můžeme konstatovat, že fungování systému vychází z expertního modelu činnosti jednotlivých složek systému a celý systém je značně citlivý na individuální rozhodnutí jednotlivých specialistů a jejich kompetenci².

Při práci s nástroji pedagogicko-psychologické diagnostiky by měl být uživatel alespoň rámcově obeznámen s klasickou teorií testů (např. Urbánek, Denglerová, Širůček, 2011). To ale vřadě př́padů představuje problém. Poměrně rozšiřrená představa o diagnostickém nástroji jej ztotožňuje s dvěma listy papíru. Na jednou jsou jednotlivé položky, na druhém klíč s vyhodnocením. Tato prezentace metod kupodivu projde i recenzním ř́́zením (více viz Mareš, 2011). Každý diagnostický nástroj, zejména v případě, kdy slouží pro nějaké zásadnější rozhodnutí o životě žáka či studenta (histakes assessment) by ale měl obsahovat - krom vlastního zadání - několik klíčových informací, bez kterých jej z odborného hlediska neodlišíme od horoskopu ve víkendové př́loze novin či testů pro pobavení, které jsou obvykle k nalezení na stejném místě. Co tedy musíme o testu vědět?

- Z jaké teorie ve vztahu ke konkrétní vlastnosti žáka či studenta vychází a jakým způsobem zjišt'ovanou charakteristiku uchopuje (operacionalizace).

- Kdo je vlastníkem autorských práv k nástroji a kde byly zveřejněny výsledky výzkumu, na jejichž základě nástroj vznikl (odborná oponentura).

- Zda obsahuje instrukce pro zadávání a upozorňuje na známé problémy (např. za jakých okolností není vhodné nástroj používat, u jakých žákủ či studentů generuje zavádějící výsledky atd.).

- Zda vychází z teorie konstrukce testů (dotazníků) a autor se zabýval analýzou položek.

- Jaká je jeho validita, např. v porovnání s jinými diagnostickými nástroji sledujícími stejnou charakteristiku.

- Jaká je jeho reliabilita, např. stabilita výsledků při zadání nástroje v mírném časovém odstupu.

\footnotetext{
${ }^{2}$ Jak funguje systém pedagogicko-psychologické diagnostiky v zahraničí? 0 tom pojednává přednáška A. Furmana (http://zp02.fss.muni.cz/Player.aspx?IdSession=39\&nbsp), který může srovnat svou zkušenost jednoho ze zakladatelů školní psychologie v České Republice a na Slovensku se svou praxí ve Spojených státech.
} 
- Zda měř́ jednu charakteristiku, když ji má měřit (ukazatelem je např. Cronbachovo alfa) či zda měří více charakteristik, ale jednotlivé škály měří vždy jen jednu (např. také Cronbachovo $\alpha$ pro každou škálu).

- Zda byl nástroj standardizován a umožňuje srovnání výsledků konkrétního žáka či žáků s jejich reprezentativním vzorkem vrstevníků.

V př́padě, že diagnostický nástroj tyto vlastnosti nemá (nejčastěji v podobě uživatelské př́ručky), je na místě velká míra ostražitosti. Zadavatelé i uživatelé výsledků diagnostiky by měli vědět, že například v př́ípadě psychologických diagnostických nástrojů nutně nemusí být laické veřejnosti známa konkrétní podoba nástroje a vyhodnocovací procedury, ale princip nástroje a výše uvedené charakteristiky ano. Jejich zatajování či nápodoba pomocí podobně znějících pojmů je jedním z typických charakteristik neodbornosti či šarlatánství.

Na rozdíl od USA a řady zemí EU včetně Slovenska není v ČR psychologie jako obor (krom dílčích částí jako je klinická či dopravní psychologie) regulován zákonem; není zde psychologická komora a psychologické odborné společnosti mají pouze poradní hlas. Za odbornou diagnostiku tak může být vydávána řada obskurních diagnostických postupů bez rizika zákonného postihu³ ${ }^{3}$

S ohledem na problémy již výše uváděné, lze současné teorie týkající se diagnostických nástrojů a např́ḱlad i rozšriření možností jejich použití v kombinaci s ICT jako je Teorie odpovědi na položku (IRT), počítačové adaptivní testování (Jelínek, Květon, Vobořil, 2011) či Teorie vědomostního prostoru (KST) (např. Denglerová in Urbánek, Denglerová, Širůček, 2011) považovat spíše za budoucí výzvy, než aktuální praxi pedagogicko-psychlogické diagnostiky.

\footnotetext{
${ }^{3}$ Př́kladem takového fenoménu v oblasti pedagogicko-psychologické diagnostiky mohou být postupy nabízené na komerční bázi firmou DAP services pod názvy „Barvy života“ či Barvy školy. Více ve varování MŠMT odborné veřejnosti (http://www.msmt.cz/ministerstvo/informace-msmt-ve-veci-metody-barvyzivota) s odkazem na Stanovisko a zdůvodnění Unie psychologických asociací ČR (http://www.upacr.cz/index.php?lng=cs\&kap=documents). Tomuto fenoménu se věnuje i H. Cígler v recenzi v tomto čísle časopisu.
} 


\section{Závěrem}

S ohledem na specifické pojetí oborů pedagogiky i psychologie lze u nás vysledovat snahu o hledání rozdílů mezi pedagogickou a psychologickou diagnostikou. Řada původně psychologických nástrojů je nyní rutinně používána kolegy z příbuzných oborů; někdy bohužel bez znalosti jejich omezení (např. speciálně-pedagogická diagnostika či sociometrie). Tento trend je ale obecný a vysledovatelný v rámci EU (např. Urbánek, 2010). Reakce psychologické komunity je dvojí - jednak větší otevřenost (problematika psychologické gramotnosti), jednak snahou o regulaci (kvalifikační standardy uživatele testů EFPA, www.efpa.eu) či uzavírání komunity (klinická psychologie).

Diagnostická aktivita učitelů je stále vnímána jako něco, co v procesu edukace ubírá čas na pro „opravdovou výuku“, nebo za projev diletantství a intelektuálního kutilství. Existuje zde tedy výrazný tlak na eliminaci diagnostických aktivit a snížení jejich časové náročnosti bez ohledu na kvalitu získaných výsledků (např. individuální vs. skupinová diagnostika). Některé diagnostické aktivity (např. srovnávací testy či autoevaluační aktivity školy) jsou vnímány spíše jako obtěžující či ohrožující administrativa, než jako nástroj podpory kvality a efektivity výuky. Navzdory aktivitám v řadě projektů (SIM, CPIV, VIP I-III atd.) je aktuální nabídka diagnostických nástrojů pro učitele i školní psychology neuspokojivá jak z hlediska rozsahu, tak z hlediska kvality. Stabilitě systému neprospívají ani nekoncepční zásahy MŠMT do pracovišt' zajišt'ujících metodickou podporu a supervizi.

Do budoucna je nutné pedagogicko-psychologické diagnostice vrátit podmínky pro její uspokojivou realizaci, at' už budeme uvažovat systematickou podporu tvorby metodiky a doporučených postupů, vlastní adaptaci nebo tvorbu i standardizaci diagnostických nástrojů jako tradiční témata. Pozornost je ale nutné věnovat i profesní přípravě prei postgraduální, a to jak učitelů, tak i psychologů. Znalost diagnostických postupů i jejich limitů je nutnou součástí odborné kvalifikace i etiky př́stupu k individuálním žákům a studentům. Tento cíl je možné naplnit přímým vzděláváním či přípravou materiálů využitelných v dílčích kurzech. Další aktivitou, která může přinést patřičnou změnu, je i snaha o informování širší laické veřejnosti. Řada témat pedagogicko-psychologické diagnostiky je v současnosti veřejně diskutována, mnohdy bez přispění psychologů. Obecná psychologická gramotnost ale může být chápána jako dlouhodobý cíl, který může přispět ke zlepšení současné, ne zcela uspokojivé situace. 


\section{Literatura}

AERA, APA, NCME (2001). Standardy pro pedagogické a psychologické testování. Praha: Testcentrum.

Čáp, J., Mareš, Jiří. (2011). Psychologie pro učitele. Praha: Portál.

Evers, A, a kol. (2012). Testing Practices in the 21st Century: Developments and European Psychologists' Opinions. European psychologist, Kirkland: Hogrefe \& HUBER PUBLISHERS, 2012, Vol. 17, No. 4, s. 300-319. doi:10.1027/1016-9040/a000102.

Furman, A. (2011). Zvýšenie užitočnosti psychologického vyšetrenia: Kolaboratívny model školskej psychológie. Konference Psychologická diagnostika dětí a dospívajících: Výzkum, prevence a školní poradenství 29. 06.-01. 07. 2011. Brno: FSS MU. Dostupný z http://zp02.fss.muni.cz/Player.aspx?IdSession=39\&nbsp.

Hrabal, V. ml. a Hrabal, V st. (2002). Diagnostika :pedagogickopsychologická diagnostika žáka s úvodem do diagnostické aplikace statistiky. 2. vyd. Praha: Univerzita Karlova v Praze, nakladatelství Karolinum.

Chvál, M., Michek, s. a kol. (2012). Cesta ke kvalitě - Modul evaluační nástroje. Praha: NÚV. Dostupný z http://evaluacninastroje.rvp.cz/.

Jelínek, M., Květon, P. \& Vobořil. D. (2011). Testování v psychologii. Praha: Grada Publishing.

Ježek, S. (2010). Standardy pro užívání psychologických testů - nastal čas pro českou normu? Testfórum. Vol 1, No 1 (2010), s. 18-22. Dostupný z http://testforum.cz/domains/testforum.cz/index.php/testforum/article/view/5/5\#.UVV iQRxhVHk.

Kožuchová, M. a kol. (2011). Pedagogická diagnostika v primárnom vzdelávaní. Bratislava: SPN.

Mareš, J. (2011). Jak neměřit ve tř́́dě. Studia Paedagogica, Vol. 16, No. 1. Dostupný z http://www.phil.muni.cz/journals/index.php/studia-paedagogica/article/view/132/234.

Novotný, V. (2000). Kargo kult, český vědecký. Vesmír, 79, květen 2000, s. 284. Dostupný z http://www.vesmir.cz/files/file/fid/2470/aid/222.

Širůček, J. (2010). Problémy psychologického testování pomocí počítače a v prostředí internetu. Testfórum. Vol 1, No 1 (2010), s. 23-26. Dostupný z http://testforum.cz/domains/testforum.cz/index.php/testforum/article/view/6/6\#.UVV mWRxhVHk.

Štech, S. a kol. (1995). Stát se učitelem. Výzkumná zpráva. Praha: UK.

Urbánek, T. (2010) Stav české psychologické diagnostiky a evropský model recenze testu. Testfórum. Vol 1, No 1 (2010), s. 2-5. Dostupný z http://testforum.cz/domains/testforum.cz/index.php/testforum/article/view/1/1\#.UVV jhhxhVHk.

Urbánek, T., Denglerová, D. \& Širůček, J. (2011). Psychometrika. Praha: Portál.

\section{Kontakt}

jmares@fss.muni.cz 